\title{
Prior Extensive Radiation
}

National Cancer Institute

\section{Source}

National Cancer Institute. Prior Extensive Radiation. NCI Thesaurus. Code C15904.

Having received extensive radiation before the present time. 